\title{
Sistem Informasi Pesediaan Obat Pada Puskesmas Kalumata Berbasis Web
}

\author{
Ikwan Hi. Sambiu ${ }^{1}$, Yusdiana Amir ${ }^{2}$ \\ Program Studi Manajemen Informatika \\ Akademi Ilmu Komputer Ternate \\ Ikwan_sambiu@gmail.com
}

\begin{abstract}
Abstrak
Puskesmas Kalumata Ternate, merupakan salah satu pusat pelayanan kesehatan masyarakat yang berada pada Kalumata kec kota ternate selatan, pada puskesmas tersebut sistem pengolahan data untuk menangani transaksi pembelian dan penjualan, mengontrol persediaan obat di gudang masih menggunakan aplikasi perkantoran yang umum digunakan yaitu Microsoft Office sehingga dianggap kurang efisien. Tujuan Penilitian ini untuk merancang satu sistem informasi persediaan obat yang lebih efektif dan efisien untuk dapat dipergunakan pada Puskesmas Kalumata Ternate, metode pengumpulan data yang digunakan yaitu observasi, wawancara, studi kepustakaan, bahasa pemrograman PHP, MySQL database yang dijalankan pada Xampp, dengan adanya penelitian ini di harapkan dapat membantu apoteker dalam mengelola data transaksi dan stok obat secara efisien yang ada pada puskesmas kalumata ternate
\end{abstract}

\section{Kata kunci: Sistem Informasi, Persediaan Obat, Website}

\begin{abstract}
Kalumata Health Center Ternate, is one of the community health service centers that are located in the Kalumata district South of ternate city, in the data processing system of clinics to handle transactions of purchase and sales, controlling the supply of drugs in the warehouse are still using Office applications commonly used Microsoft Office so that it is considered less efficient. The goal of research is to design a drug that supplies information systems more effective and efficient to be used at healt center Kalumata Ternate. Data collection methods used are observation, interview, literature study, PHP programming language, MySQL database running on Xampp. the existence of this study expect may assist the pharmacist in managing data transaction and stock medicines efficiently on Healt Center kalumata Ternate
\end{abstract}

Keywords: Information Systems, Medical Supplies, Website

PENDAHULUAN

Masyarakat semakin menuntut tersedianya kemudahan-kemudahan di segala bidang yang mampu menunjang berbagai bidang usaha. Untuk mendukung kemajuan itu semua, sangat diperlukan suatu pertukaran informasi atau komunikasi yang lebih cepat, kapan saja dan di manapun mereka berada. Untuk itu manusia akan mengupayakan seoptimal mungkin kemampuan untuk berkomunikasi.
Dengan berbagai kelebihan dan kemudahan yang ditawarkan tentu akan meningkatkan efisiensi dan efektivitas kerja dari satu perusahaan. Salah satu kelebihan dari sistem komputerisasi ialah menghasilkan informasi secara relevan, tepat waktu dan akurat. Informasi yang dihasilkan tidak terlepas dari manajemen informasi yang baik dan mampu menjaga kelancaran kebutuhan informasi dalam sirkulasi data satu sistem.

Manajemen sistem informasi juga menyangkut adanya satu basis data yang 
mampu mengorganisasikan data yang ada di dalamnya secara akurat dan mampu mengatur relasi antar data sehingga informasi yang dihasilkan berdaya guna dan berpengaruh pada proses pengambilan keputusan pihak manajemen perusahaan. Untuk membangun satu sistem informasi memerlukan pemahaman yang baik dan jelas mengenai sistem yang akan digunakan baik dalam prosedur sistem, input, output maupun hal-hal yang mempengaruhi kinerja sistem baik untuk jangka pendek maupun jangka panjang.

Puskesmas Kalumata, merupakan salah satu pusat pelayanan kesehatan masyarakat yang berada pada Kalumata kec kota ternate selatan, pada puskesmas tersebut sistem pengolahan data untuk menangani transaksi pembelian dan penjualan, mengontrol persediaan obat di gudang masih menggunakan aplikasi perkantoran yang umum digunakan yaitu Microsoft Office.

Untuk itu diperlukan satu sistem informasi yang mampu meningkatkan kinerja sistem agar dapat memberikan hasil yang maksimal serta dapat meningkatkan efisiensi dan efektivitas kerja dengan menggunkan sistem yang terkomputerisasi dengan menggunakan pemrograman website

\section{Rumusan Masalah}

Kegiatan pengontrolan obat baik dalam persediaan, pembelian dan penjualan yang masih dikerjakan dengan aplikasi perkantoran yaitu Microsoft Office. Laporan persediaan yang dihasilkan kurang terperinci

Sehingga penelitian ini dapat di rumuskan adalah bagaimana merancang sistem informasi persediaan obat pada puskesmas kalumata ternate

\section{Tujuan Penelitian}

Untuk merancang satu sistem informasi persediaan obat yang lebih efektif dan efisien untuk dapat dipergunakan pada Puskesmas Kalumata.

\section{Manfaat Penelitian}

1. Mengetahui alur logistik dalam sistem logistik di Puskesmas Kalumata dengan mengembangkan model simulasi.

2. Mendapatkan model simulasi sistem logistik pada Puskesmas Kalumata untuk membantu manajemen Puskesmas dalam membuat keputusan yang tepat dan efisien untuk kebijakan logsitik.

\section{Tinjauan Pustaka}

Penelitian terdahulu sangat penting sebagai dasar dalam rangka penyusunan penelitian ini. Kegunaannya untuk mengetahui hasil yang telah dilakukan oleh peneliti terdahulu. Adapun penelitian yang diteliti adalah:

Suhindra (2013) Aplikasi Persediaan Barang Pada Puskesmas Mantrijeron. Pada penelitian ini yang bertempat di Yogyakarta dan bahasa pemrograman yang berbeda.

Lindawaty (2008). Sistem Informasi Persediaan Obat pada Apotik Dunia. Pada penelitian ini dilaksanakan di Medan Sumatera Utara dan tidak berbasis web.

Penelitian di atas hampir sama dengan penulis tetapi perbedaanya bahasa pemrograman yang penulis pakai yaitu PHP (Hypertext Processor) dan berbasis web.

\section{LANDASAN TEORI}

Pengertian Sistem

Menurut Sutabri

(2012:10)

menjelaskan, "Sistem diartikan sebagai 
kumpulan atau himpunan dari unsur, komponen, atau variabel yang terorganisir, saling berinteraksi, saling tergantung satu sama lain, dan terpadu.

\section{Pengertian Informasi}

Informasi merupakan hasil pengolahan data sehingga menjadi bentuk yang penting bagi penerimanya dan mempunyai kegunaan sebagai dasar dalam pengambilan keputusan yang dapat dirasakan akibatnya secara langsung saat itu juga atau secara tidak langsung pada saat mendatang. Untuk memperoleh informasi, diperlukan adanya data yang akan diolah dan unit pengolah. (Edhy Sutanta, 2003).

\section{Pengertian Sistem Informasi}

Istilah sistem informasi sebenarnya terdiri atas dua kata kunci, yaitu sistem, dan informasi. Sebagaimana telah disinggung di atas, cara yang lebih baik untuk memberikan definisi Sistem Informasi adalah dimulai dengan memahami istilah sistem dan informasi. Selanjutnya berdasarkan pemahaman yang diperoleh dapat digunakan untuk memberikan definisi tentang sistem informasi, yaitu menggabungkan ketiga kata kunci tersebut. (Edhy Sutanta, 2003)

\section{Analisis Sistem}

Analisis sistem (system analysis) merupakan tahap setelah perencanaan sistem sebelum perancangan sistem. Analisis sistem sangat menentukan keberhasilan pengembangan sistem informasi, karena kesalahan dalam tahap ini akan mempengaruhi langkah pengembangan sistem selanjutnya. Bagan alir sistem akan digambarkan dalam tahap ini sebagai alat komunikasi antara analis sistem dan pemakai, serta personil yang terlibat di dalam tim.

Tahapan analisis sistem meliputi kegiatan sebagai berikut:

1. Menentukan kebutuhan informasi.

2. Menentukan kriteria kinerja sistem.

Laporan ke manajemen

\section{DFD (Diagram Flow Data)}

Menurut Sutabri (2012:116), Data Flow Diagram adalah suatu network yang menggambarkan suatu system automat atau komputerisasi, manualisasi, atau gabungan dari keduanya, yang penggambaranya disusun dalam bentuk kumpulan komponen sitem yang saling berhubungan sesuai aturan mainya

Keuntungan penggunaan DFD adalah memungkinkan untuk menggambarkan sistem dari level yang paling tinggi kemudian menguraikannya menjadi level yang lebih rendah (dekomposisi). Sedangkan kekurangan penggunaan DFD adalah tidak menunjukkan proses pengulangan (looping), proses keputusan dan proses perhitungan.

\section{Rancangan Input}

Rancangan Input merupakan jembatan yang menghubungkan sistem informasi dengan dana yang dimiliki oleh USER dan tergantung apakah sistem tersebut Online / Batch.

Tujuan Dari Rancangan Input:

1. Mengontrol Jumlah Data Input

proses penyiapan dan pemasukkan data sangat tergantung pada manusia, dengan mengurangi kuantitas kebutuhan data, maka akan mengurangi biaya.

2. Menghinari Kesalahan Data

Kesalahan data, dapat dikurangi dengan rancangan input yang baik, 
dengan teknik validasi (program komputer)

3. Menghindari Keterlambatan Proses Keterlambatan proses biasanya disebabkan oleh pemasukkan data yang bersifat menunggu (Bottle Neck), kita harus menghindarinya.

4. Merancang Pengolahan Yang Sederhana Rancangan sistem yang baik, harus sesuai dengan orang yang mengoperasikannya dan mudah dipahami (user friendly) tanpa melupakan aspek kontroling data.

5. Menentukan Kebutuhan Input Sistem Baru Bentuk input yang akan dirancang dapat ditentukan dari data flow diagram (DFD) sistem baru yang telah dibuat dengan melihat dataflow yang terjadi dari satu proses ke proses lainnya.

6. Menentukan Parameter Dokumen Input Setelah bentuk output dirancang, maka selanjutnya menentukkan PARAMETER dari dokumen INPUT tersebut, (Fungsi, Sumber, Tujuan, Frekwensi, Kondisi, Media dan Bentuk)

\section{ERD (Entity Relationship Diagram)}

Menurut Brady dan Loonam (2010), dalam bahasa indonesia bahwa Entity Relationship diagram (ERD) merupakan teknik yang digunakan untuk memodelkan kebutuhan data dari suatu organisasi, biasanya oleh System Analys dalam tahap analisis persyaratan proyek pengembangan system. Sementara seolah-olah teknik diagram atau alat peraga memberikan dasar untuk desain database relasional yang mendasari sistem informasi yang dikembangkan.

\section{PHP}

PHP adalah singkatan dari "PHP: Hypertext Prepocessor", yaitu bahasa pemrograman yang digunakan secara luas untuk penanganan pembuatan dan pengembangan sebuah situs web dan bisa digunakan bersamaan dengan HTML. PHP diciptakan oleh Rasmus Lerdorf pertama kali tahun 1994. Pada awalnya PHP adalah singkatan dari "Personal Home Page Tools". Selanjutnya diganti menjadi FI ("Forms Interpreter"). Sejak versi 3.0, nama bahasa ini diubah menjadi "PHP: Hypertext Prepocessor" dengan singkatannya "PHP". PHP versi terbaru adalah versi ke-5. Berdasarkan survey Netcraft pada bulan Desember 1999, lebih dari sejuta site menggunakan PHP, di antaranya adalah NASA, Mitsubishi, dan RedHat.

\section{MySQL}

MySQL adalah sebuah perangkat lunak sistem manajemen basis data SQL (database management system) atau DBMS yang multithread, multiuser,dengan sekitar 6 juta instalasi di seluruh dunia. MySQL AB membuat MySQL tersedia sebagai perangkat lunak gratis dibawah lisensi GNU General Public License (GPL), tetapi mereka juga menjual dibawah lisensi komersial untuk kasus-kasus dimana penggunaannya tidak cocok dengan penggunaan GPL

\section{Xampp}

Pengertian XAMPP adalah perangkat lunak (free software) bebas, yang mendukung untuk banyak sistem operasi, yang merupakan kompilasi dari beberapa program. Fungsi XAMPP sendiri adalah sebagai server yang berdiri sendiri (localhost), yang terdiri beberapa program antara lain: Apache HTTP Server, MySQL 
database, dan penerjemah bahasa yang ditulis dengan bahasa pemrograman PHP danPerl. Nama XAMPP sendiri merupakan singkatan dari $\mathrm{X}$ (empat sistem operasi apapun), Apache, MySQL, PHP dan Perl. Program ini tersedia dalam GNU General Public License dan bebas, merupakan web server yang mudah untuk digunakan yang dapat menampilkan halaman web yang dinamis. Untuk mendapatkannya XAMPP anda dapat mendownload langsung dari web resminya. Dan berikut beberapa definisi program lainnya yang terdapat dalam XAMPP

\section{METODE PENELITIAN}

1. Observasi

Penelitian dengan cara pemusatan objek yang sedang diteliti, dalam hal ini penulis melihat dan mengamati secara langsung sistematika kerja di lapangan.

2. Wawancara

Melakukan tanya jawab langsung dengan staf atau karyawan pada lokasi penelitian.

3. Studi kepustakaan

Dengan mencari dan mengumpulkan data yang diperlukan dari berbagai buku-buku, catatan-catatan, dan gambar-gambar yang menunjang penyusunan laporan tugas akhir ini.

\section{Adobe Dreamweaver}

Adobe Dreamweaver adalah program yang digunakan untuk membuat atau menyunting halaman web. Software Dreamweaver dikeluarkan oleh Adobe Sistem. Aplikasi ini banyak digunakan oleh para programmer, desainer dan developer web dikarenakan kemudahan dalam penggunaanya, kelengkapan fiturnya dan juga dukungannya terhadap teknologi terkini. Adobe Dreamweaver menyediakan fitur editor WYSIWYG (What You See is What You Get) atau dalam bahasa kesehariannya disebut Design View. Maksudnya adalah, tampilan hasil akhir web kita nanti akan sama dengan tampilan pada saat proses perancangan halaman web. Dengan segala fitur yang ada pada Adobe Dreamweaver, membuat suatu web bukanlah hal yang sulit. Kita tidak perlu menguasai berbagai macam bahasa pemrograman web seperti HTML, CSS, Javascript, PHP, dan sebagainya. Cukup mengetahui dasar dasarnya saja, karena didalam aplikasi ini sudah disediakan alat alat otomatis. Selain itu, aplikasi ini juga menyediakan 3 macam tampilan yaitu Code View, Design View dan Split View. Code View cocok untuk para programmer yang terbiasa dengan kode kode pemrograman web. Sedangkan Design View cocok untuk para Designer yang terbiasa dengan visual. Jika ingin menggunakan keduanya, bisa memilih Split View.

\section{Kerangka Berpikir}

Mengamati sistem yang digunakan pada

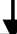

Menganalisis sistem yang berjalan dan membuat analisis sistem yang diusulkan

Membuat sistem informasi yang diusulkan

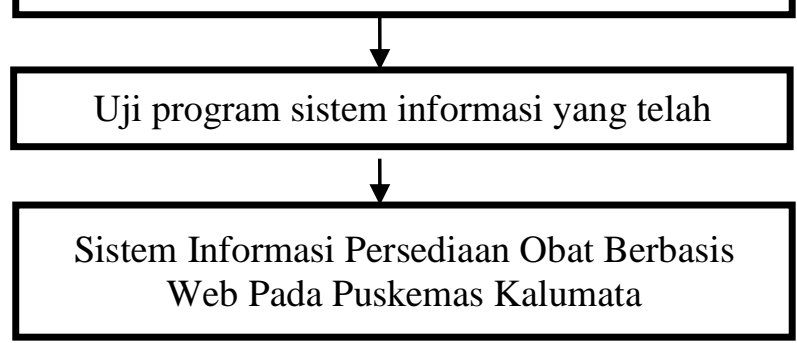

Gambar 1. Kerangka Berpikir

ANALISIS DAN PERANCANGAN

Sesuai dengan analisis sistem yang berjalan pada Sistem Informasi Persediaan 
Obat Berbasis web pada Puskesmas Kalumata mengenai pendataan obat, maka penulis memberikan pemecahan masalah dengan perancangan sistem informasi persediaan obat, sistem ini mempermudah bagian administrasi untuk mendata obat masuk dan keluar, berikut merupakan gambar sistem yang berjalan pada puskesmas kalumata

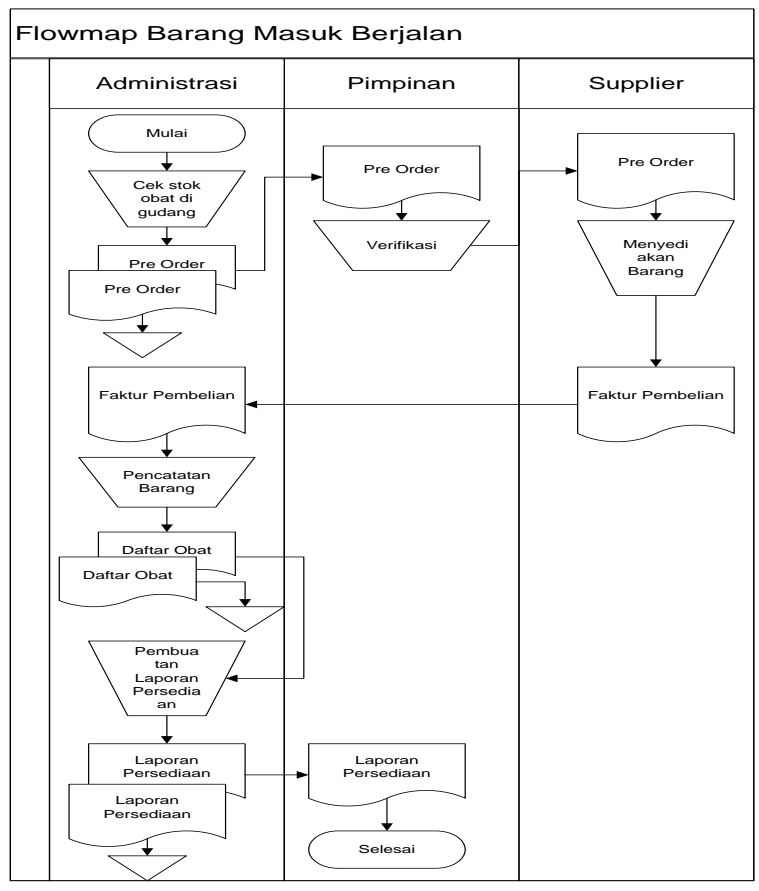

Gambar 2. Analisis Sistem berjalan

Berdasarkan analisis sistem yang sedang berjalan tentang persediaan obat, maka penulis memberikan suatu pemecahan masalah dengan perancangan sistem yang berbasis web. Aplikasi ini merupakan komponen penting dalam pembuatan Tugas Akhir ini. Aplikasi persediaan obat ini berfungsi untuk memberikan informasi kepada bagian Admnistrasi dan pemakainya, berikut merupakan bagan analisis sistem uyang diusulkan

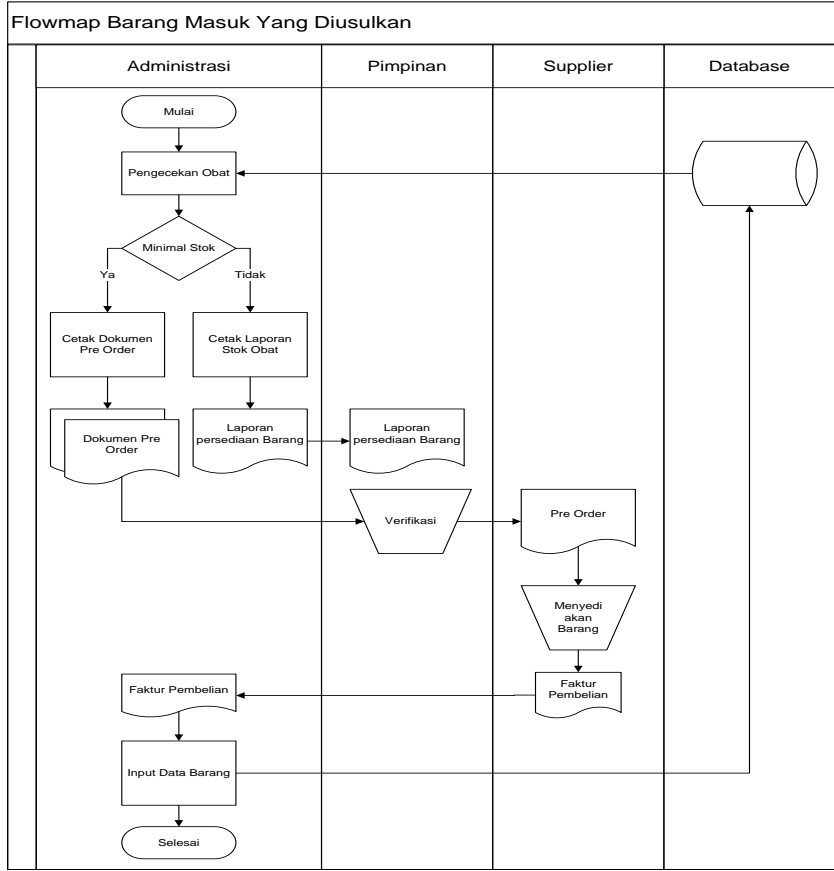

Gambar 3. Analisis Sistem yang diusulkan

\section{Diagram Konteks}

Diagram konteks merupakan alat bantu dalam perancangan global bagi program aplikasi yang dibuat. Tujuannya adalah untuk mencerminkan keadaan sistem yang akan dibangun secara umum. Adapun diagram konteks untuk Sistem Inforasi Persediaan Obat Pada Puskesmas Kalumata adalah:

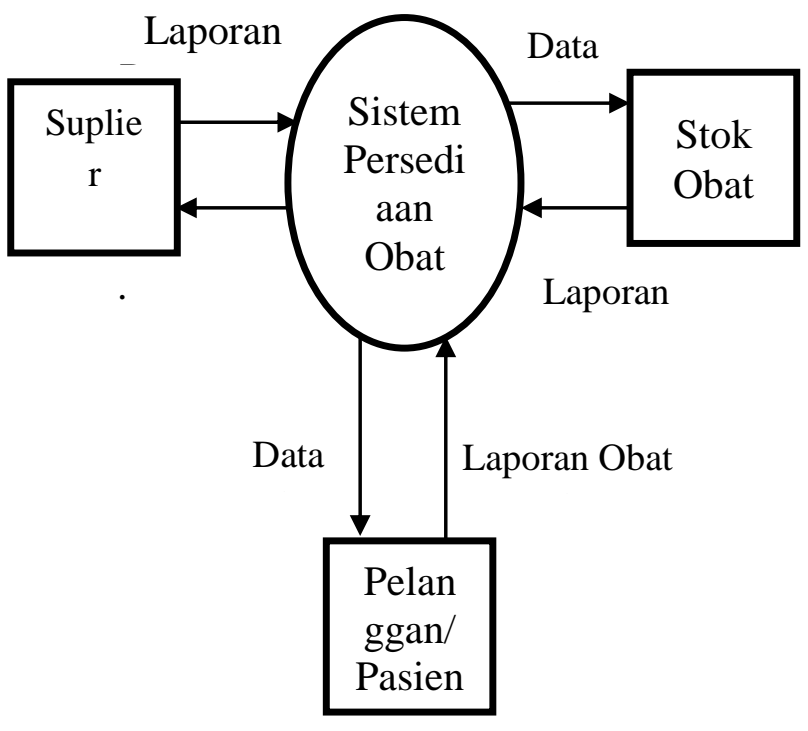

Gambar 4. Diagram Konteks 


\section{DFD Level 0}

DFD Level 0 merupakan awal dari aliran data. Pada DFD Level 0 menggambarkan aliran data secara umum. Pada DFD Level 0 ini menggambarkan bagian stok barang memberikan laporan stok barang kepada sistem dari data obat yang telah diproses

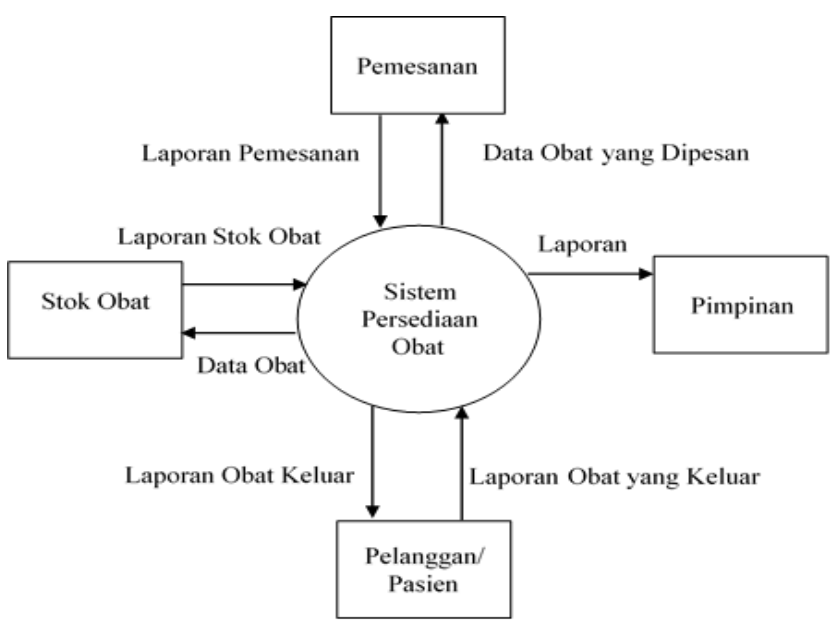

Gambar 5. Diagram Level 0

\section{DFD Level 1}

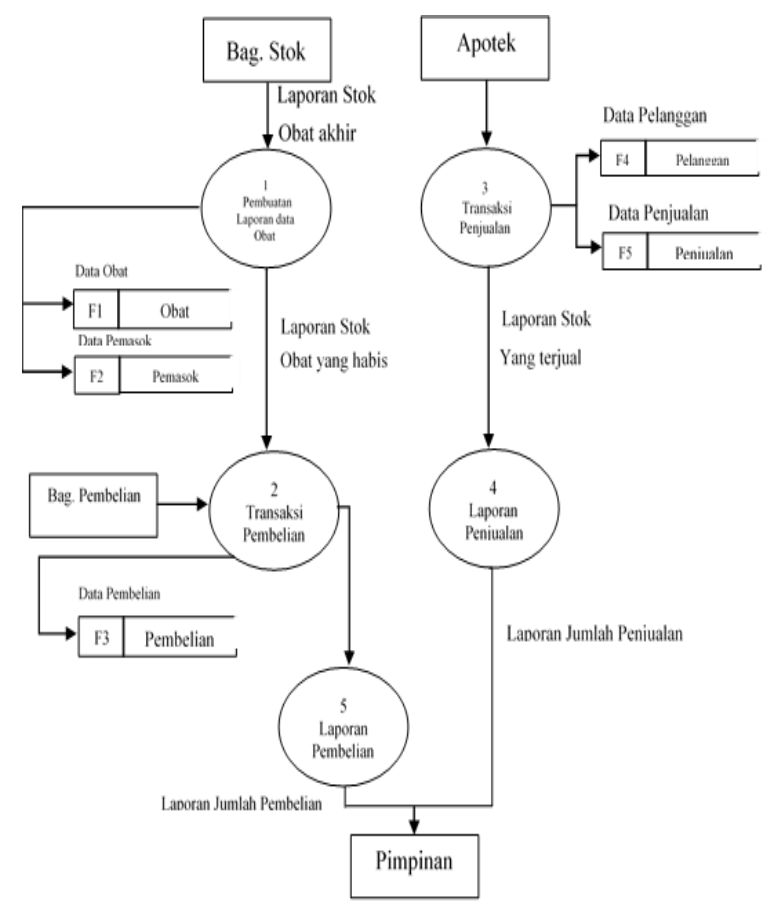

Gambar 6. Diagram Level 1

\section{Kamus Data}

Kamus data adalah suatu kumpulan data elemen yang terstruktur dengan pengertian yang konsisten dan sesuai dengan sistem, sehingga pengguna maupun analis sistem memiliki pemahaman yang sama mengenai masukan, keluaran dan komponen simpanan data. Berikut merupakan rancangan kamus datanya

Tabel 1. Login Admin

\begin{tabular}{lc|ccc} 
Nama Arus Data & & : Admin \\
Penjelasan & & : Data Admin & & \\
Periode & \multicolumn{2}{c}{ : Setiap kali input data user terjadi } \\
Bentuk & \multicolumn{2}{c}{ :Dokumen } & & \\
Struktur Data & $:$ & & & \\
\hline \multicolumn{1}{c|}{ Name } & Type & Width & Index & Keterangan \\
\hline id & integer & 10 & Primary Key & Auto_Increment \\
\hline user & varchar & 20 & & NamaUser \\
\hline password & varchar & 10 & & Password \\
\hline
\end{tabular}

Tabel 2. Data Obat

\begin{tabular}{|c|c|c|c|c|}
\hline \multirow{5}{*}{\multicolumn{2}{|c|}{$\begin{array}{l}\text { Nama Arus Data } \\
\text { Penjelasan } \\
\text { Periode } \\
\text { Bentuk } \\
\text { Struktur Data }\end{array}$}} & \multicolumn{3}{|c|}{ : Tbl obat } \\
\hline & & \multicolumn{3}{|c|}{ : Data Obat } \\
\hline & & \multicolumn{3}{|c|}{ : Setiap kali input data tersimpan } \\
\hline & & \multicolumn{3}{|c|}{ : Dokumen } \\
\hline & & & & \\
\hline Name & Type & Width & Index & Keterangan \\
\hline kd_obat & integer & 20 & Primary Key & \\
\hline jenis_obat & varchar & 255 & & \\
\hline tgl_masuk & date & & & \\
\hline nm_obat & varchar & 255 & & \\
\hline exp_date & date & & & \\
\hline $\begin{array}{l}\text { hrg_pokok } \\
\text { hrg_jual }\end{array}$ & $\begin{array}{l}\text { currency } \\
\text { currency }\end{array}$ & & & \\
\hline $\begin{array}{l}\text { banyak } \\
\text { Id_pemasok }\end{array}$ & $\begin{array}{l}\text { Big integer } \\
\text { integer }\end{array}$ & $\begin{array}{c}255 \\
20\end{array}$ & Foreign Key & \\
\hline
\end{tabular}

Tabel 3. Pemasok

\begin{tabular}{|c|c|c|c|c|}
\hline \multirow{5}{*}{\multicolumn{2}{|c|}{$\begin{array}{l}\text { Nama Arus Data } \\
\text { Penjelasan } \\
\text { Periode } \\
\text { Bentuk } \\
\text { Struktur Data }\end{array}$}} & \multirow{5}{*}{\multicolumn{3}{|c|}{$\begin{array}{l}\text { :Tbl_pemasok } \\
\text { : Data Pemasok } \\
\text { : Setiap kali input data tersimpan } \\
\text { : Dokumen }\end{array}$}} \\
\hline & & & & \\
\hline & & & & \\
\hline & & & & \\
\hline & & & & \\
\hline Name & Type & Width & Index & Keterangan \\
\hline Id pemasok & integer & 20 & Primary Key & Auto_increment \\
\hline nama & varchar & 255 & & \\
\hline alamat & text & 255 & & \\
\hline No_telp & varchar & 30 & & \\
\hline kota & varchar & 255 & & \\
\hline
\end{tabular}


Tabel 4. Stok

\begin{tabular}{|c|c|c|c|c|}
\hline \multirow{5}{*}{\multicolumn{2}{|c|}{$\begin{array}{l}\text { Nama Arus Data } \\
\text { Penjel asan } \\
\text { Periode } \\
\text { Bentuk } \\
\text { Struktur Data }\end{array}$}} & \multicolumn{3}{|c|}{ : Tbl_stok } \\
\hline & & \multicolumn{3}{|c|}{ : Menampilkan informasi banyak stok obat } \\
\hline & & \multicolumn{3}{|c|}{ Setiap kali input data tersimpan } \\
\hline & & \multicolumn{3}{|c|}{ : Dokumen } \\
\hline & & & & \\
\hline Name & Type & Width & Index & Keterangan \\
\hline Id_stok* & integer & 20 & Primary Key & Auto_increment \\
\hline Kd_obat & integer & 20 & Foreign Key & \\
\hline Jenis_obat & varchar & 255 & & \\
\hline Nm_obat & varchar & 255 & & \\
\hline Tgl_masuk & date & & & \\
\hline Exp_date & date & & & \\
\hline Harga pokok & currency & & & \\
\hline Harga jual & currency & & & \\
\hline banyak & Big integer & & & \\
\hline
\end{tabular}

Tabel 5. Barang Keluar

\begin{tabular}{|c|c|c|c|c|}
\hline \multicolumn{2}{|c|}{$\begin{array}{l}\text { Nama Arus Data } \\
\text { Penjelasan } \\
\text { Periode } \\
\text { Bentuk } \\
\text { Struktur Data } \\
\end{array}$} & \multicolumn{3}{|c|}{$\begin{array}{l}\text { Tbl_stok_keluar } \\
\text { : Dipakai ketika obat dibeli atau keluar } \\
\text { : Setiap kali input data tersimpan } \\
\text { : Dokumen }\end{array}$} \\
\hline Name & Type & Width & Index & Keterangan \\
\hline Id_penjualan & integer & 255 & Primery Key & Nomor penjualan \\
\hline kd_obat & integer & 20 & Foreign Key & Kode obat \\
\hline Jenis_obat & varchar & 255 & & Jenis obat yang akan dijual \\
\hline $\mathrm{Nm}$ obat & varchar & 255 & & Nama obat \\
\hline Exp_date & date & & & Tanggal kadarluarsa \\
\hline harga & date & & & Harga Jual \\
\hline banyak & currency & & & Jumlah obat yang dijual \\
\hline $\begin{array}{l}\text { jumlah } \\
\text { diskon }\end{array}$ & $\begin{array}{l}\text { currency } \\
\text { currency }\end{array}$ & & & $\begin{array}{l}\text { Jumlah uang yang harus } \\
\text { dibayar } \\
\text { Potongan Harga }\end{array}$ \\
\hline
\end{tabular}

\section{ERD (Entity Relationship Diagram)}

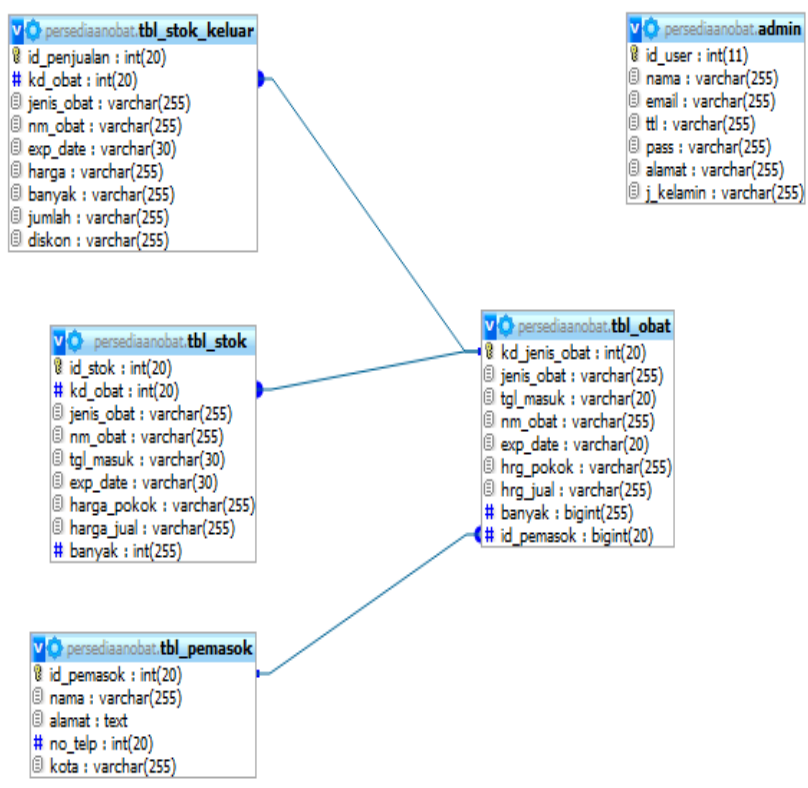

Gambar 7. Relasi antar Tabel

\section{Rancangan Input Terinci}

\section{Data Obat}

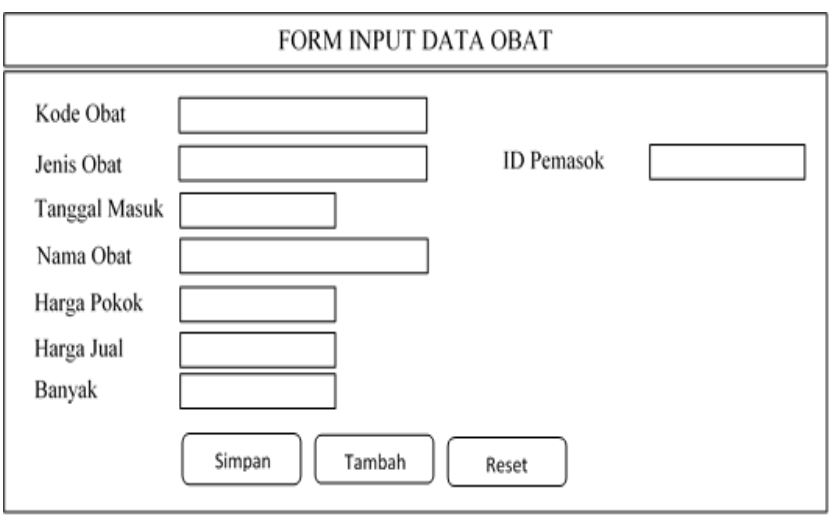

Gambar 8. Form data obat

\section{Data Pemasok}

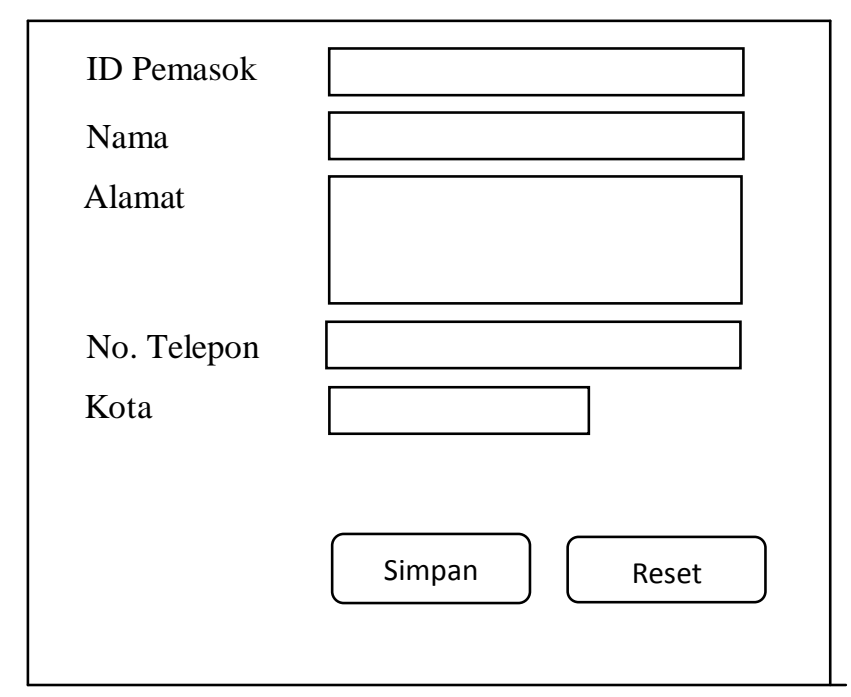

Gambar 9. Form Data Pemasok

\section{Data Obat Keluar}

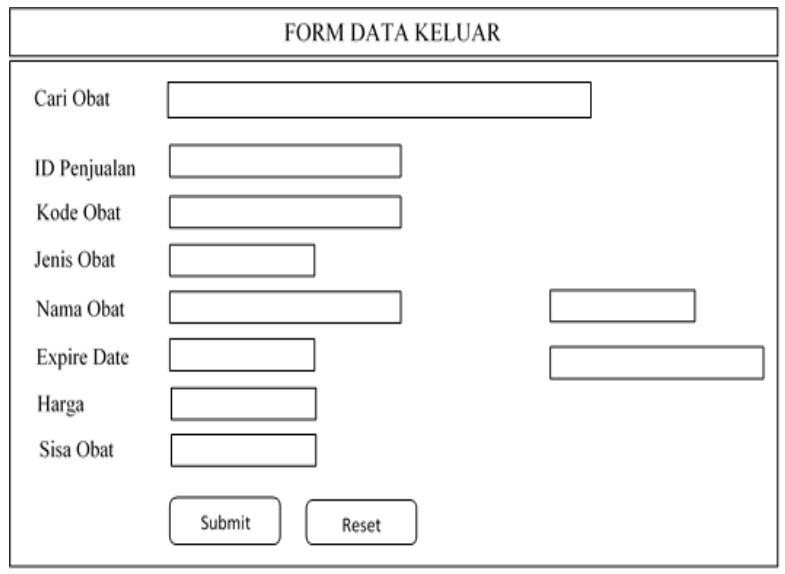

Gambar 10. Form obat keluar 


\section{IMPLEMENTASI DAN PEMBAHASAN}

Implementasi sistem (system implementation) adalah tahap meletakkan sistem supaya siap dioperasikan. Kegiatan implementasi dilakukan dengan dasar kegiatan yang telah direncanakan dalam kegiatan implementasi antara lain : pemilihan dan pelatihan personil, instalasi hardware dan software, pengetesan program, pengetesan sistem dan konversi sistem

\section{Perangkat Keras yang dibutukan}

Tabel 6. Spesifikasi Perangkat Keras

\begin{tabular}{|c|c|}
\hline \multicolumn{2}{|c|}{ SPESIFIKASI KOMPUTER } \\
\hline Mainboard & Intel \\
\hline Processor & Intel Atom \\
\hline Memory & $128 \mathrm{MB}$ \\
\hline HDD & $60 \mathrm{~GB}$ \\
\hline Lain-lain & $\begin{array}{c}\text { Monitor, Keyboard, } \\
\text { Mouse, Printer }\end{array}$ \\
\hline
\end{tabular}

Perangkat Lunak yang dibutuhkan

1. Sistem Operasi Windows 7 Professional

2. Adobe Dreamwear

3. XAMP

4. MySQL

5. Mozila Firefox

\section{Form Menu Login}

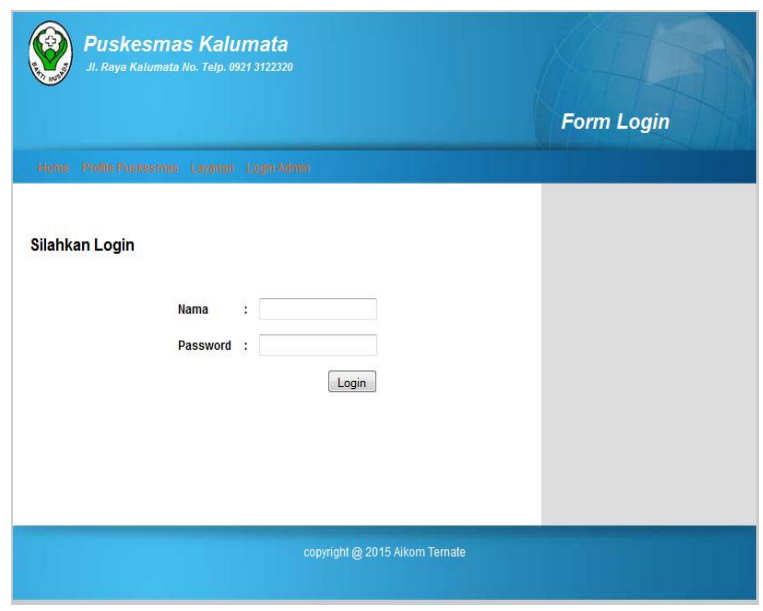

Gambar 11. Menu Login

\section{Form Menu Index Home}

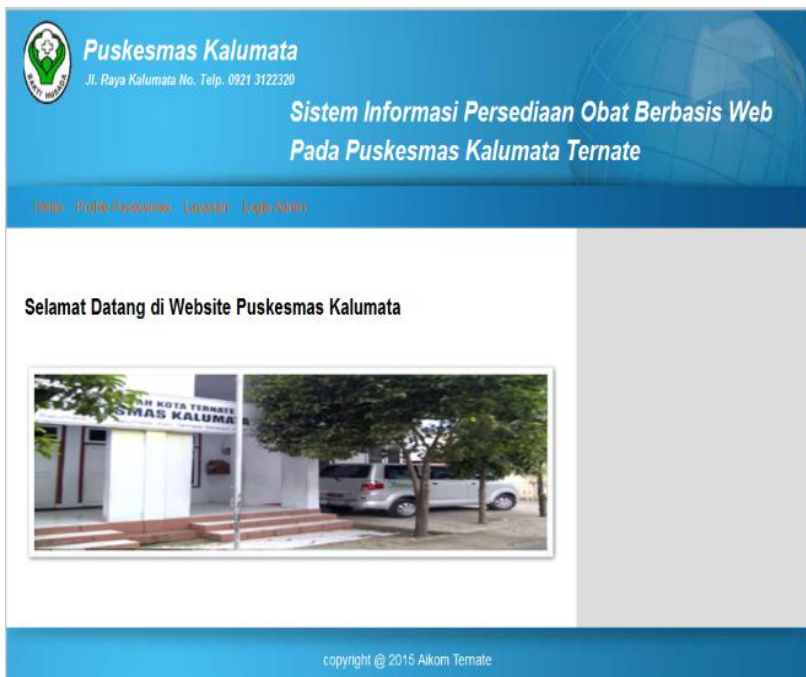

Gambar 12. Menu Index Home

\section{Form Menu Input Obat}

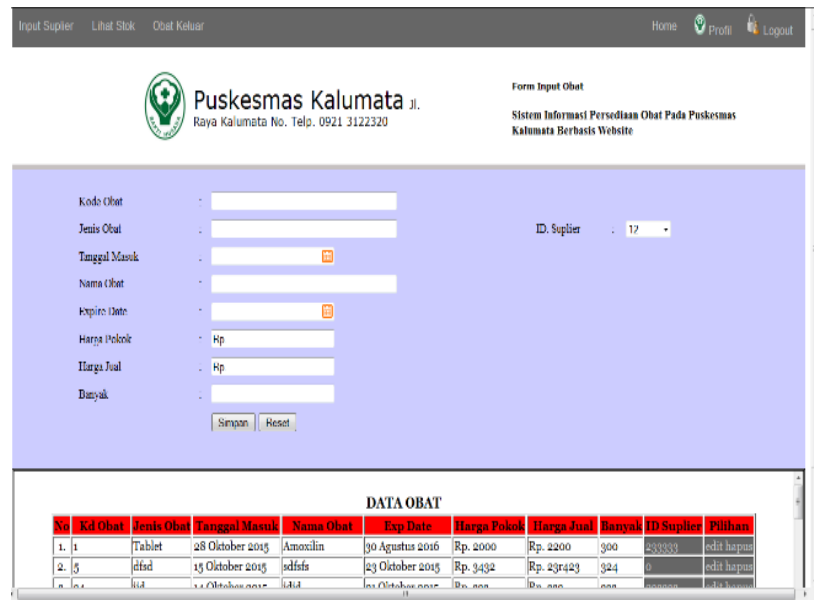

Gambar 13. Menu input obat

\section{Form Menu Supplier}

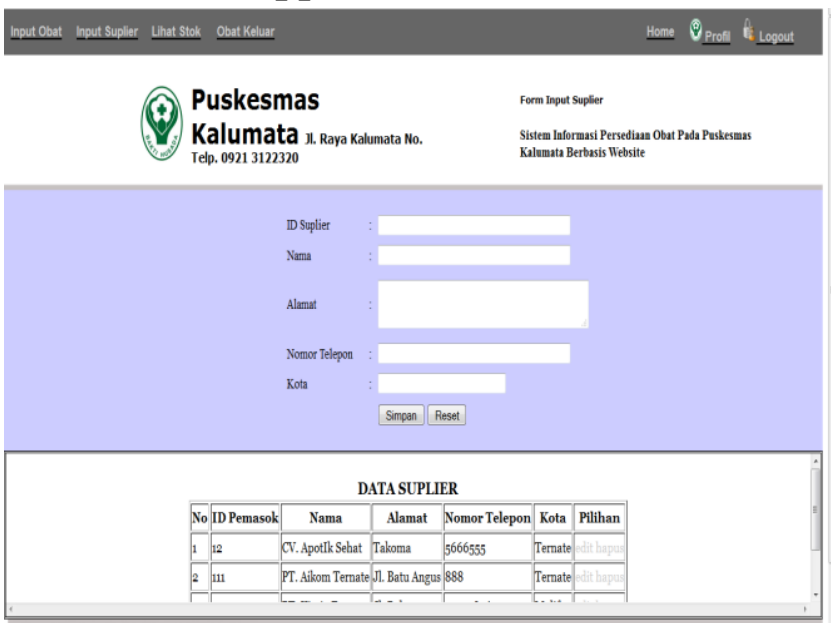

Gambar 14. Menu supplier 


\section{Form Menu Stok}

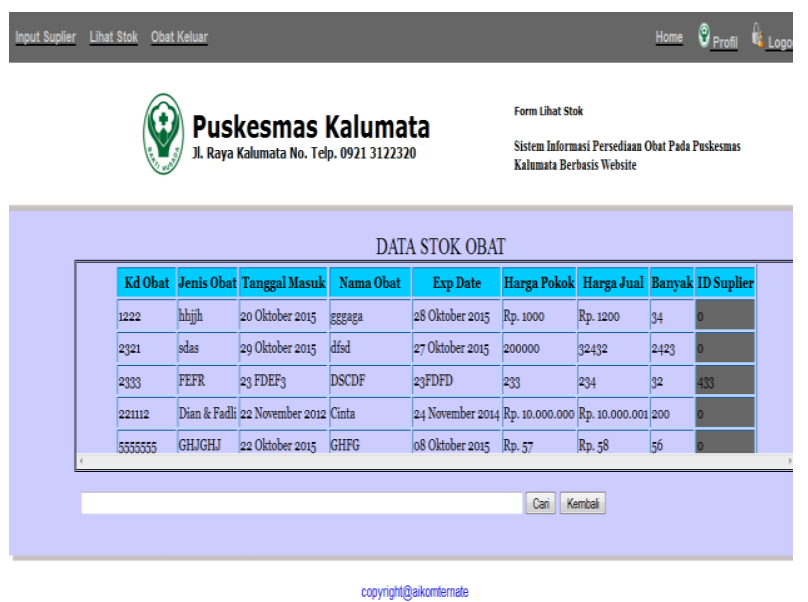

Gambar 15. Menu Stok

\section{KESIMPULAN}

Berdasarkan hasil uji perancangan dan analisis penelitian pada Puskesmas Kalumata maka dapat penulis simpulkan

Kalumata menggunakan sistem manual (Microsoft Office Excel 2010). Oleh karena itu, penulis kembangkan sistem yang sudah berbasis Web (Aplikasi Dreamweaver, dan MySQL). Adapun Sistem Informasi yang dibuat menyangkut dengan:

1. Penyajian sistem informasi stok obat yaitu dari pembelian, penjualan dan stok obat yang dilakukan secara otomatis akan lebih mudah dan cepat persediaanya.

2. Aplikasi program yang dibuat sangat membantu apoteker dalam mengelola stok obat

\section{Saran}

Berdasarkan hasil uji coba perancangan Sistem Informasi stok obat pada Puskesmas Kalumata maka ada beberapa saran yang ingin penulis berikan sebagai bahan masukan untuk menyempurnakan sistem yang dibuat, yaitu:
1. Pemberian pelatihan pengoperasian komputer pada pegawai sangat diperlukan untuk meningkatkan ketrampilan pegawai dan meminimalkan kesalahan saat bekerja.

2. Pengaturan sistem harus disesuaikan dengan aturan dan sumber daya manusia agar tercipta keoptimalan kerja serta perlu adanya inovasi dalam pemanfaatan teknologi secara baik.

\section{DAFTAR PUSTAKA}

Al Fatta, Hanif (2007). Analisis dan Perancangan Sistem Informasi: Untuk Keunggulan Bersaing Perusahaan dan Organisasi Modern. Yogyakarta: Andi Offset

Brady, M.,\& Loonam, J., 2010. Exploring the use of entity-relationship diagramming as a technique to support grounded theory inquiry. Bradford:Emerald Group Publishing Hartono, Jogiyanto. (1990). Analisis dan Desain Sistem Informasi: Pendekatan Terstruktur. Yogyakarta: Andi Offset.

Jogiyanto. (2005). Perancangan sistem. Jakarta : Graha Ilmu

Lindawaty (2008). Sisstem Informasi Pesediaan Obat Pada Apotik Dunia. Medan: Tugas Akhir Universitas Sumatera Utara

Scoot (1986). Prinsip Sistem Informasi Manajemen. McGraw-Hill International Co., New York.

Suhindra (2013). Aplikasi Persediaan Barang Berbasis Website Pada Puskesmas Mantrijeron. Tugas Akhir. Yogyakarta

Sutanta, Edhy (2003). Sistem Informasi Manajemen. Sentolo, Kulon Progo: Penerbit Graha Ilmu

Tata Sutabri. 2012, Konsep Sistem Informasi. Andi. Yogyakarta

Tata Sutabri. 2012. Analisis Sistem Informasi. Andi. Yogyakarta

Winarni, Tutik. (2007). Sistem Informasi Stok Obat Apotek. Surakarta: TA, Universitas Sebelas Maret 